\title{
Electrochemical Behaviour of Metal Alloy SS316 in Artificial Blood Plasma in the Presence of Metformin500
}

\author{
S. John Mary ${ }^{1}$, J. Mano Deepa ${ }^{2}$, Karishma Kundu ${ }^{3}$, Selvam ${ }^{4}$ \\ Loyola Institute of Frontier Energy (LIFE) \\ Loyola College (Affiliated to University of Madras) \\ Chennai - 600034, Tamil Nadu, India
}

\begin{abstract}
To study the corrosion behaviour of metal alloy SS316 in artificial blood plasma in the presence of Metformin500. The amount of drug was taken in 50ppm and $100 \mathrm{ppm}$ amounts and they have been allowed to settle down for 40 days. The $\mathrm{pH}$ of artificial blood plasma has to be maintained at 7.2. Potentiodynamic polarisation and AC impedance studies have to be carried out to investigate the corrosion behaviour of metal alloys.
\end{abstract}

Metformin500

Key words- Corrosion, Artificial Blood Plasma, SS316,

\section{INTRODUCTION}

Metformin, marketed under the trade name Glucophage among others, is the first-line medication for the treatment of type 2 diabetes, particularly in people who are overweight. It is also used in the treatment of polycystic ovary syndrome. It is not associated with weight gain. It is taken by mouth. Metformin is generally well tolerated. Common side effects include diarrhea, nausea, and abdominal pain. It has a low risk of causing low blood sugar [13]. High blood lactic acid level is a concern if the medication is prescribed inappropriately or in overly large doses [1]. It should not be used in those with significant liver disease or kidney problems. While no clear harm comes from use during pregnancy, insulin is generally preferred for gestational diabetes. Metformin is a biguanide antihyperglycemic agent. It works by decreasing glucose production by the liver and increasing the insulin sensitivity of body tissues.

Metformin was discovered in 1922. French physician Jean Sterne began study in humans in the 1950s. It was introduced as a medication in France in 1957 and the United States in 1995.Metformin is on the World Health Organization's List of Essential Medicines, which lists the most effective and safe medicines needed in a health system. Metformin is the most widely used medication for diabetes taken by mouth[7]. It is available as a generic medication. SS316L alloys are the most commercially successful implantation material in biomedical. SS316L alloys are widely used as orthopedic implant materials in clinical practice; stainless steel is one of the representatives of metallic biomaterials [2]. This is mainly due to their good corrosion resistant properties. The stainless steels typically used in medicine are austenitic stainless steels. These stainless steels contain $17-20 \% \mathrm{Cr}, 13-15 \% \mathrm{Ni}, 2-$
3\% molybdenum and small amount of other elements [3]. The notation "L" indicates that the steel has low carbon content $(<0.03 \%)$ and is therefore not susceptible to intergranular corrosion; due to precipitation of $\mathrm{Cr}$-carbides at the grain boundaries, stainless steel implants are used as temporary implants to help bone healing, as well as fixed implants such as artificial joints. In terms of corrosion resistance in the human body, stainless steels are inferior compared to cobalt, chromium and titanium alloys [4].

Many metals and alloys have been used in implantation. Influence of $\mathrm{pH}$ and corrosion inhibitor antibiotic drug in ABP has been investigated. The selection of materials for medical applications is usually based on considerations of biocompatibility [5]. When metals are considered, the susceptibility of the material to corrosion and the effect the corrosion has on the tissue are the central aspects of biocompatibility. The human body is not an environment that one would consider hospitable for an implanted metal alloy. Corrosion results in releasing toxic metals ions to body and also weakening implants [6]. An electrochemical reaction involves removing electrons from the anode to the cathode. When the metal is surrounded by an aqueous solution, oxidation may occur at the location on the metal surface. Corrosion resistance of implant materials may involve qualitative measurements or quantitative electrochemical measurements in simulated body fluid [8].

\section{MATERIALS AND METHODS}

The present work is undertaken. The metal specimens, namely, SS316 has been chosen for the present study.

\begin{tabular}{|l|l|}
\hline \multicolumn{1}{|c|}{ Composition } & \multicolumn{1}{c|}{ Percentage (\%) } \\
\hline $\mathrm{Ni}$ & 12.00 \\
\hline $\mathrm{Cr}$ & 17.00 \\
\hline $\mathrm{Mo}$ & 2.50 \\
\hline $\mathrm{Fe}$ & Balance \\
\hline $\mathrm{Si}$ & 1.00 \\
\hline $\mathrm{Mn}$ & 2.00 \\
\hline $\mathrm{C}$ & 0.080 \\
\hline $\mathrm{P}$ & 0.045 \\
\hline $\mathrm{S}$ & 0.030 \\
\hline
\end{tabular}

Table 1 Composition of SS 316

The metal specimen was encapsulated in Teflon. The metal specimen was polished to mirror finish and degreased with trichloroethylene. The metal specimen was immersed in artificial blood plasma. 
Table II Chemical composition of

the artificial blood plasma according to

PN-EN ISO 10993-15 standard (g/l distilled water)

\begin{tabular}{|l|l|}
\hline \multicolumn{1}{|c|}{ Composition } & \multicolumn{1}{c|}{ Gram (g) } \\
\hline $\mathrm{NaCl}$ & 6.800 \\
\hline $\mathrm{KCl}$ & 0.4 \\
\hline $\mathrm{CaCl}$ & 0.2 \\
\hline $\mathrm{MgSO}$ & 0.1 \\
\hline $\mathrm{NaHCO}_{3}$ & 2.2 \\
\hline $\mathrm{Na}_{2} \mathrm{HPO}_{4}$ & 0.126 \\
\hline $\mathrm{NaH}_{2} \mathrm{PO}_{4}$ & 0.026 \\
\hline
\end{tabular}

In electrochemical studies the metal specimen was used as working electrode and Artificial blood plasma was used as electrolyte $(10 \mathrm{ml})$.

\section{A. Potentiodynamic Polarization}

Polarization studies were carried out in a CHI Electrochemical workstation with impedance, Model 660A. A three-electrode cell assembly was used. The working electrode was the metal specimen. A saturated calomel electrode (SCE) was the reference electrode and platinum was the counter electrode. From the polarization study, Corrosion parameters such as corrosion potential $\left(\mathrm{E}_{\text {corr }}\right)$, corrosion current $\left(\mathrm{I}_{\text {corr }}\right)$ and Tafel slopes (anodic $=$ $\mathrm{b}_{\mathrm{a}}$ and cathodic $=\mathrm{b}_{\mathrm{c}}$ ) were calculated [9].

\section{B. AC Impedance Spectra}

The instrument used for polarization study was used to record AC impedance spectra also. The cell setup was also the same. The real part (Z') and imaginary part (Z') of the cell impedance were measured in ohms at various frequencies. Values of the charge transfer resistance $\left(R_{t}\right)$ and the double layer capacitance $(\mathrm{Cdl})$ were calculated from Nyquist plots, impedance $\log (\mathrm{Z} / \mathrm{ohm})$ value was calculated from bode plots [10].

\section{RESULTS AND DISCUSSIONS}

\section{A. Analysis of Potentiodynamic polarization curves}

The corrosion behaviour of SS316 in artificial bold plasma in absence and presence of Metformin 500 (Fig.1) is studied by polarization study and AC impedance spectra. Corrosion parameters such as corrosion potential, corrosion current, linear polarization resistance, charge transfer resistance and double layer capacitance have been derived from these studies [11,12]. Metformin 500 reduces the amount of glucose (sugar) made by our liver by decreasing the amount of glucose our body absorbs and increasing the effect of insulin on your body. Insulin is a hormone that helps your body removes extra sugar from your blood, Thus lowers your blood sugar levels. There are two main types of diabetes: type 1 and type 2 . Both types of diabetes are chronic diseases that affect the way your body regulates blood sugar. Glucose is the fuel that feeds your body's cells, but to enter your cells it needs a key. Insulin is that key. Melting point: $223-226{ }^{\circ} \mathrm{C}$, Water Solubility: Soluble in water, IUPAC Name: 3-(diaminomethylidene)-1,1dimethylguanidine, Brand name: Glucophage or Glumetza. People with type 2 diabetes have insulin resistance. The body still produces insulin, but it's unable to use it effectively. Researchers aren't sure why some people become insulin resistant and others don't, but several lifestyle factors may contribute, including excess weight and inactivity. Other genetic and environmental factors may also contribute. Because of your body is unable to effectively use insulin, glucose will accumulate in your bloodstream. The main objective of present study is to

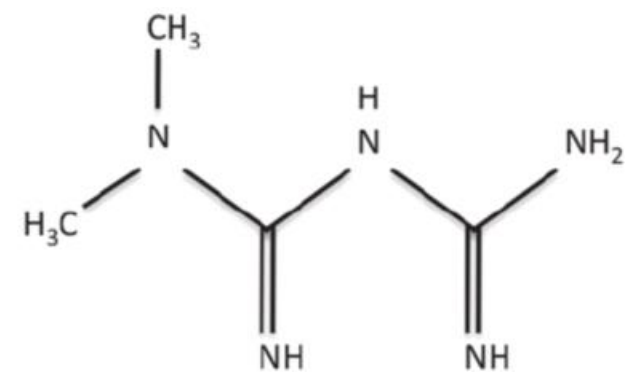

investigate how the intake of a metformin500solution affects the diabetics who have undergone implantation. Hence the corrosion behaviour of SS316 in absence and presence of 50ppm and 100ppm Metformin 500 is studied. Fig.1.Chemical structure of Metformin

The potentiodynamic polarization curves of SS316 immersed in artificial blood plasma in the absence and presence of metformin500 are shown in Figs.1.1 to 1.3. Corrosion parameters, namely corrosion potential, Ecorr, Icorr, Tafel slopes, $b_{a}, b_{c}$, and LPR are given in the Table1. Polarization study has been used to confirm the formation of protective a film on the metal surface during the corrosion inhibition process. If a protective film is formed on the metal surface, the linear polarization resistance (LPR) increases and the corrosion current value (Icorr) decreases.

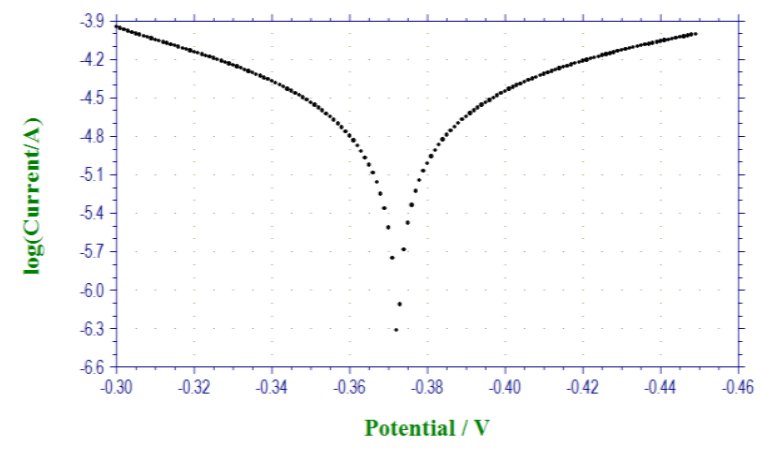

Fig 1.1 Polarization curve of SS316+ABP (Control) 
Fig 1.2 Polarization curve of SS316+ ABP $+\quad 50 \mathrm{ppm}$ of Metformin500

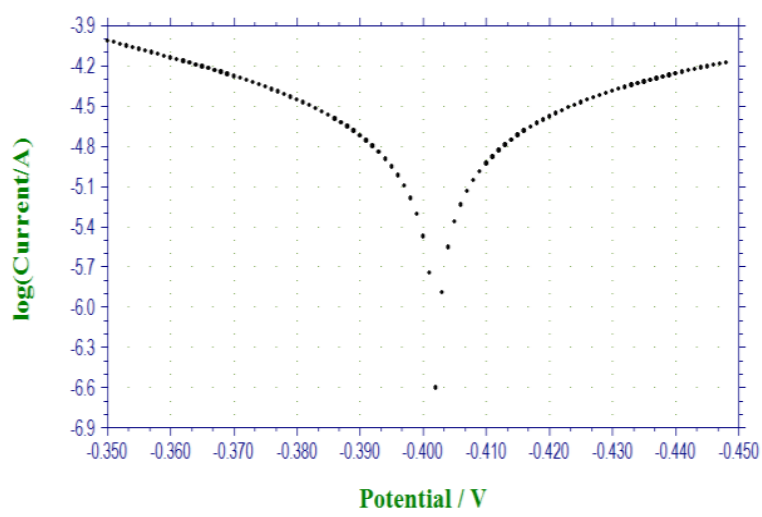

Fig 1.3 Polarization curve of SS316 + ABP + 100ppm of Metformin500

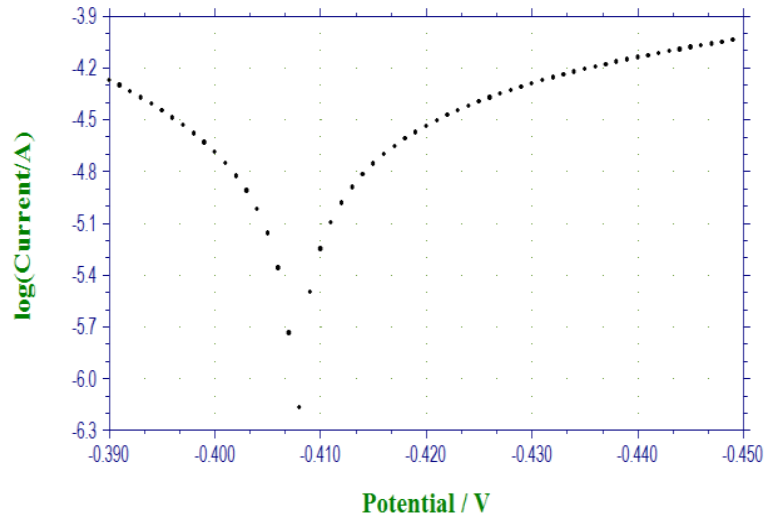

Table 1- Polarization results for SS316 immersed in ABP, in the absence ofMetformin 500, in the presence of 50ppm and 100ppm Metformin500

\begin{tabular}{|c|c|c|c|c|c|c|}
\hline $\begin{array}{l}\text { MET } \\
\text { AL }\end{array}$ & System & $\begin{array}{c}E_{\text {corr }} \\
\text { mv vs } \\
\text { SCE }\end{array}$ & $\begin{array}{c}\boldsymbol{\beta}_{\mathrm{c}} \\
\mathrm{mV} / \mathrm{dec} \\
\mathrm{ade}\end{array}$ & $\begin{array}{c}\beta_{\mathrm{a}} \\
\mathrm{mV} / \mathrm{d} \\
\text { ecade }\end{array}$ & LPR & $\begin{array}{l}\mathbf{I}_{\text {corr }} \\
\mathbf{A} / \mathbf{c} \\
\mathbf{m}^{2}\end{array}$ \\
\hline \multirow{3}{*}{$\begin{array}{l}\text { SS } \\
316\end{array}$} & $\begin{array}{l}\text { Control } \\
\text { (ABP+ } \\
\text { METAL) }\end{array}$ & 437 & 420 & 440 & $\begin{array}{l}8.33 \\
10^{5}\end{array}$ & -408 \\
\hline & $\begin{array}{l}\text { ABP } \\
\text { METAL } \\
\text { Metformin } \\
500-0.05 \mathrm{~g}\end{array}$ & 408 & 430 & 450 & $\begin{array}{l}2.51 \\
10^{7}\end{array}$ & -617 \\
\hline & $\begin{array}{l}\text { ABP + } \\
\text { METAL + } \\
\text { Metformin } \\
500-0.1 \mathrm{~g}\end{array}$ & 402 & 400 & 448 & $\begin{array}{l}6.79 \\
10^{7}\end{array}$ & -660 \\
\hline
\end{tabular}

\subsection{SS316 immersed in ABP:}

When the SS316is immersed in artificial blood plasma the corrosion potential is $437 \mathrm{mV}$ and the corrosion current is $-408 \mathrm{~A} / \mathrm{cm}^{2}$. In tafel slopes, the cathodic value is $420 \mathrm{mV}$ and anodic value is $440 \mathrm{mV}$.

1.2 SS316 immersed in ABPin presence of $50 \mathrm{ppm}$ Metformin500:

The SS316 when it is immersed in artificial blood plasma with $0.05 \mathrm{~g}$ of Metformin 500 the corrosion potential shifted to the cathodic side. The cathodic Tafel value is higher than the anodic value which indicates that the change of current with the change of potential was high in the cathodic region than in the anodic region. This is due to the formation of a protective film on the anodic sites of the metal surface. This prevents the corrosion of metal.

\subsection{SS316 immersed in ABPin presence of $100 \mathrm{ppm}$} Metformin500:

The SS316 when it is immersed in artificial blood plasma with $0.1 \mathrm{~g}$ of Metformin 500 the corrosion potential is 402 and the cathodic Tafel value is 400 and anodic Tafel value is 448. This indicates that this is more corrosion resistant than SS316 in ABP contained Metformin500 - 50 $\mathrm{ppm}$. A protective layer was formed on the metal surface.

\section{B. Analysis of AC impedance spectra}

The AC impedance parameters namely charge transfer resistance (Rt) and double layer capacitance (Cdl) derived from Nyquist plots of SS316 immersed in artificial saliva in absence and in presence of Metformin500. AC impedance spectra have been used to confirm the formation of a protective film on the metal surface.If a protective film is formed on the metal surface, charge transfer resistance (Rt) increases, double layer capacitance value (Cdl) decreases.(Fig.2.1 to 2.3).

Fig 2.1 Nyquist Plot of SS316 + ABP

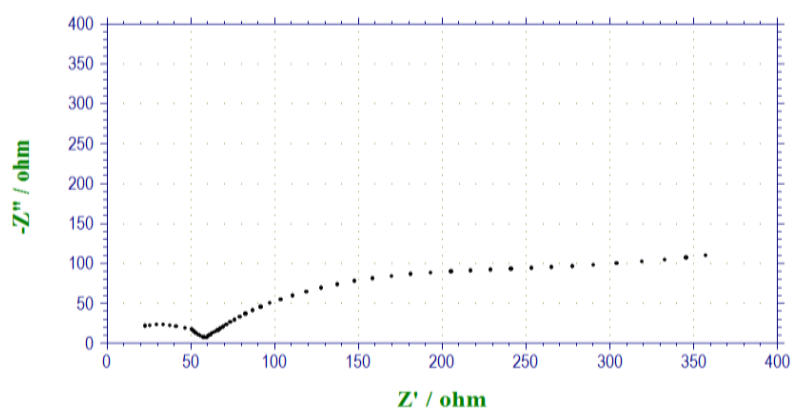

Fig 2.2 Nyquist Plot of SS316 + ABP + 50ppm of Metformin500

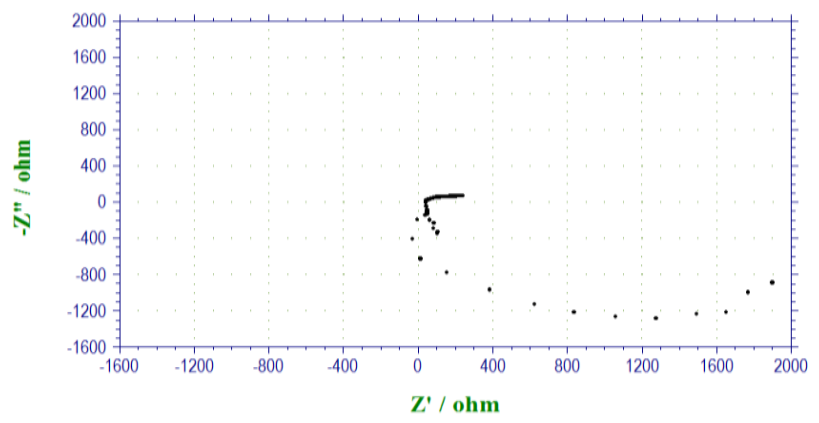

Fig 2.3 Nyquist Plot of SS316 + ABP + 100ppm of Metformin500

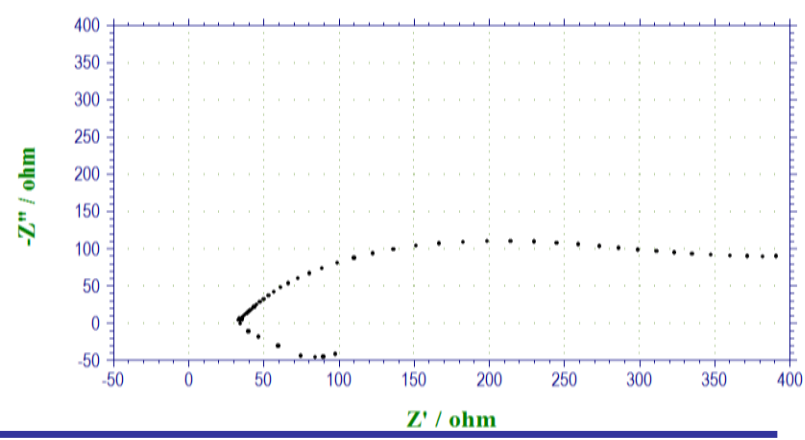


Table 2 - AC impedance results for SS316 immersed in ABP, in the absence of Metformin500, in the presence of 50ppm and 100ppm Metformin500

\begin{tabular}{|c|c|c|}
\hline \multirow[b]{2}{*}{ System } & \multicolumn{2}{|c|}{ Nyquist plot } \\
\hline & Rt ohm $/ \mathrm{cm}^{2}$ & $\mathrm{Cdl} \mathrm{F} / \mathrm{cm}^{2}$ \\
\hline $\mathrm{SS} 316 \mathrm{~L}+\mathrm{ABP}$ & 341.1 & $1.49 \times 10^{-8}$ \\
\hline $\begin{array}{l}\mathrm{SS} 316 \mathrm{~L}+\mathrm{ABP}+50 \\
\mathrm{ppm} \text { of metformin } \\
500\end{array}$ & 959.0 & $5.31 \times 10^{-9}$ \\
\hline $\begin{array}{l}\mathrm{SS} 316 \mathrm{~L}+\mathrm{ABP}+ \\
100 \text { ppm of } \\
\text { metformin } 500\end{array}$ & 1200.0 & $4.25 \times 10^{-9}$ \\
\hline
\end{tabular}

\subsection{SS316immersed in ABP}

The SS316 immersed in artificial blood plasma shows the charge transfer resistance value as $526 \mathrm{ohm} \mathrm{cm}^{2}$. The cdl value is $9.695 \times 10^{-09} \mu \mathrm{F} / \mathrm{cm}^{2}$.The impedance value is 3.1 .

2.2 SS316 immersed in ABPin presence of $50 \mathrm{ppm}$ Metformin500

In the presence of Metformin500 0.05g the Rt value is increased and the impedance value also is getting increased. This shows that the protective film is formed on the metal surface. The rate of corrosion resistance is high.

\subsection{SS316 immersed in ABPin presence of $50 \mathrm{ppm}$} Metformin500

In the presence of Metformin 0.1g the Rt value increases and decrease in $\mathrm{Cdl}$ value and impedance value too increases indicating the rate of corrosion resistance is higher than Metformin500 $50 \mathrm{ppm}$ and this is because of the protective film formed on the metal surface.

SS316 + ABP+ 100ppm Metformin500 > SS316+ABP + 50ppm Metformin500> SS316+ ABP

\section{CONCLUSION}

The corrosion behaviour of SS316 immersed in ABP in absence and presence of $50 \mathrm{ppm}$ and 100ppmMetformin500 have been studied.

Polarization study leads to the following conclusions.

SS316 + ABP+ 100ppm Metformin500 > SS316+ABP + 50ppm Metformin500> SS316+ ABP

AC impedance leads to the following conclusions.

SS316 + ABP+ 100ppm Metformin500 > SS316+ABP + 50ppm Metformin500> SS316+ ABP

\section{REFERENCE}

[1] Corrosion behavior of metals in the presence of spirilina by Dr.S.johnmary, Dr. rajendiran.Dr. S .johnmary, Dr . Nagalakshm and Dr.rajendiran Corrosion behavior of SS316L in the presence of electrol

[2] S. John Mary, S.Rajendran Corrosion Behavior of Ni-Cr In Artificial Blood Plasma In Presence Of Shelcal-Vitamin D Journal of Convergence, ISSN 0972-6489 Vol 12, No.1- 4(2011) pg77-84.

[3] Corrosion behavior of metals in the presence of spirilina by Dr.s.johnmary, Dr.Rajendiran.Corrosion behavior of SS316L in the presence of electrol by Dr. S .johnmary, Dr. Nagalakshmi, Dr.rajendiran.

[4] Yang, Y.; Kim, K.; Agrawal, C. \& Ong, J. (2004). Interaction of hydroxyapatite-titanium at elevated temperature in vacuum environment. Biomaterials, Vol.25, No.15, (July2004), pp. 2927 2932, ISSN 01429612

[5] Niinomi, M. (1999). Recent titanium R\&D for biomedical applications in Japan. JOMJournalof the Minerals, Metals and Materials Society, Vol.51, No.6, (June 1999), pp. 32-34, ISSN10474838

[6] Liu, Y., \& Baker, T.N. (1995). Deformation characteristics of IMI685 Ti alloy under isothermal forging conditions. MaterSciEngA, 197, 125.

[7] Li, P.; Kangasniemi, I. \& De Groot, K. (1994). Hydroxyapatite Induction by a Gel-Derived Titania on a Titanium Substrate. Journal of the Ceramic Society, Vol.77, No.5, (May 1994), pp. $1307-1312$

[8] Di Mario, C., Griffiths, H., Goktekin, O., Peeters, N., Verbist, J., Bosiers, M., Deloose, K.,Heublein, B., Rohde, R., Kasese, V., Ilsley, C. \&Erbel, R. (2004). Drug-elutingbioabsorbable magnesium stent. JIntervCardiol, 17, 391.

[9] Currey, J. (1998). Mechanical properties of vertebrate hard tissues. Proceedings of the Institution of Mechanical Engineers, Part H: Journal of Engineering in Medicine, Vol.212,No.6, (1998), pp. 399-411, ISSN 09544119

[10] Chen, Q., Liu, L. \& Zhang, S.-M. (2010). The potential of Zrbased bulk metallic glasses asbiomaterials. Front Mater Sci China, $4,34$.

[11] ASTM (2007b). ASTM F 562: Standard Specification for Wrought 35Cobalt-35Nickel- 20Chromium-10Molybdenum Alloy for Surgical Implant Applications (UNSR30035), West Conshohocken, ASTM International.

[12] ASTM (2003). ASTMF138:Standard Specification for Wrought 18chromium-14nickel- 2.5molybdenum Stainless Steel Bar and Wire for Surgical Implants (UNS S31673),WestConshohocken, ASTM International.

[13] S. John Mary and S. Rajendran, Corrosion Behavior of SS316L in Artificial Blood Plasma in Presence of D-Glucose, International Journal of Engineering Inventions, 1(6), 2012, 06-12 